\title{
Research on Design Resource Allocation of New Energy Power Generation
}

\author{
Xiangxiang Liu \\ State Gird Jiangxi Electric Power Research Institute
}

\begin{abstract}
Keywords: New Energy Power Generation; Electricity Market; Wind Power Generation; Distribution Network; Grid Connected Technology
\end{abstract}

\begin{abstract}
In recent years, a steady increase in the number of new energy power generation projects, the new energy power design enterprises to carry out a number of design projects at the same time has become the norm. The new energy power generation technology is the use of renewable resources, through natural resource recycling, reduce the pollution of the natural world and energy saving, the power generation technology is more green. In this multi project environment, the inter project human resources competition is also increasingly fierce, so there are many project human resource management issues. Therefore, new energy power generation design enterprises need to study and solve how to properly coordinate the allocation of resources, to carry high resource use efficiency and realize the goal of enterprise's overall project.
\end{abstract}

\section{Introduction}

The massive use of fossil fuels has brought about two major problems of resource depletion and climate change, which have seriously threatened the sustainable development of human society. To seek a clean and sustainable alternative energy is a historical challenge for the energy industry. Solar, wind and other new energy gradually attracted people's attention with its characteristics of renewable and clean. In the process of the development of new energy prices is the energy competition in key only when new and renewable sources of energy in the price of the traditional energy form compared and energy turnover of through market competition gradually. Energy prices affected by energy policy, technological progress and other factors, so the scientific and rational energy development strategy, technology research and development strategy will play a huge role in promoting the new energy revolution.

In this paper, the structure of China's energy, distribution characteristics and the way of energy storage, is focusing on to wind power, solar photovoltaic power generation as the representative of the new energy power generation output characteristic equation, simulation and analysis of the output characteristics of power. The influences of wind power generation and photovoltaic power generation on power system planning, operation, protection, economy and so on analyzed. Focuses on the analysis of wind power, solar photovoltaic power generation,grid model and dynamic model of the economy, for the large-scale use of wind energy and solar energy to provide some new suggestions.

\section{Development and Application Status of New Energy Power Generation Technology}

The extensive use of fossil fuels has brought about the problems of resource depletion, environmental pollution and climate change, which have seriously threatened the sustainable development of human society. Especially after entering the 21 st century, new energy and renewable energy entered the period of a rapid development, has gradually become the strategic direction of the force of the global energy system and the development of energy in the future.

The definition of new energy: on the basis of new technology, system development and utilization of renewable energy, such as nuclear energy, solar energy, wind energy, biomass energy, geothermal energy, ocean energy, hydrogen. New energy is also known as non-conventional energy sources. Refers to the various forms of energy beyond the traditional energy sources. Compared 
with traditional fossil energy, new energy has two distinct characteristics: one is the renewable and recyclable, two large reserves, less pollution.

The wind is a great potential in the new energy, although wind power on the site is very high, to occupy large tracts of land, the cost is relatively high, but if you can effective use of earth can be used for power generation of the wind, then it will be 10 times around the world the amount of hydroelectric power. Wind power is clean, renewable, short construction period, installed flexible, Chinese have wind power equipment in order to focus on energy strategy, and expected to maintain a rapid development in the next period. Clean solar energy is also affected by the energy of people of all ages, the majority of the sources of energy needed by the human beings is the sun, is the sun directly or indirectly bring us tremendous energy, on the full use can greatly increase the power supply.

\section{New Energy Power Generation Characteristics}

Wind Power Generation Model and Its Dynamic Characteristics Analysis. The energy source of the original motive of the wind turbine generator is the kinetic energy of the natural stroke. Due to the variability of wind speed and is not controllable, wind turbine almost every hour of the day was subjected to a greater degree of disturbance such perturbations whether the unit itself or on the connected with power system, will produce a certain degree of influence. Therefore, dynamic simulation analysis of wind power generation system needs to establish a mathematical model.

In the moving process of wind, there is not only the change of kinetic energy, but also the change of potential energy. In a certain period of time and space, the change of wind speed is random. In order to change when the simulated wind speed accurately reflect the characteristics of randomness and intermittence of wind energy, time and space is commonly used to model the basic wind, wind, wind and wind gradient noise of the 4 typical model to simulate the change of wind speed.

Model and Dynamic Characteristics Analysis of Solar Photovoltaic Power Generation. To the east of earth rotation on its axis from west to form the alternation of day and night, and the rotation of the earth around the sun. The Earth's axis of rotation and revolution of the orbit plane (ecliptic plane) inclined to the normal 23.45-degree angle. Because of the earth's rotation and revolution, relative to the plane, the position of the sun constantly is changing. In the equatorial coordinate system, the position of the sun determined by the time angle $\omega$ and the latitude angle two variables.

The location of the direct point of the sun in a year is always moving between degrees and + 23.45 degrees in the north and south. Red taboo angle definition of Wei sun point, namely the center of the sun and the earth connection and the equatorial plane angle, XXX said that the Cooper equation approximate calculation obtained by

$$
\delta \approx 23.45 \sin \left(360 \times \frac{284+n}{365}\right)
$$

In the formula, $n$ is the date ordinal of a year, defined as $n=1$ in January 1 st. The solar zenith angle is a function of latitude, latitude and longitude, and its expression is

$$
\sin \alpha=\cos \theta_{z}=\sin \delta \sin \phi+\cos \delta \cos \phi \cos \omega
$$

Installation angle of the photovoltaic cell panel selected and the optimal dip angle is 34.4 degrees. The temperature and the amount of radiation data in the calculation of the weather forecast using the recorded temperature and irradiance data.

\section{Research on Grid Connected Technology of New Energy Power Generation and Distribution}

Solar power generation divided into two categories: solar thermal power generation and solar photovoltaic power generation. The solar thermal power generation system is mainly composed of a heat collecting part, a transmission part and a heat storage part. According to the different light gathering system, it divided into solar thermal power generation system, trough solar thermal power generation system and disk type solar thermal power generation system. 
Solar power is that without by thermal process directly converts light energy into electrical energy generating form, including photovoltaic power generation, photochemical generation, light induction generator and bio optical power, currently the most commonly used for photovoltaic power generation. Photovoltaic power generation using solar energy semiconductor electronic devices absorb the sun radiation, and transforming it into electric energy of a direct generation of power. At present, the most widely used solar cells in the world are a single crystal baby solar cells, solar cells, thin film solar cells and so on.

The schematic diagram of the grid connected photovoltaic power generation system shown in Fig. 1. The system is mainly composed of a photovoltaic cell simulator, MPPT charging controller, super capacitor, storage battery, sine wave inverter and system monitor.

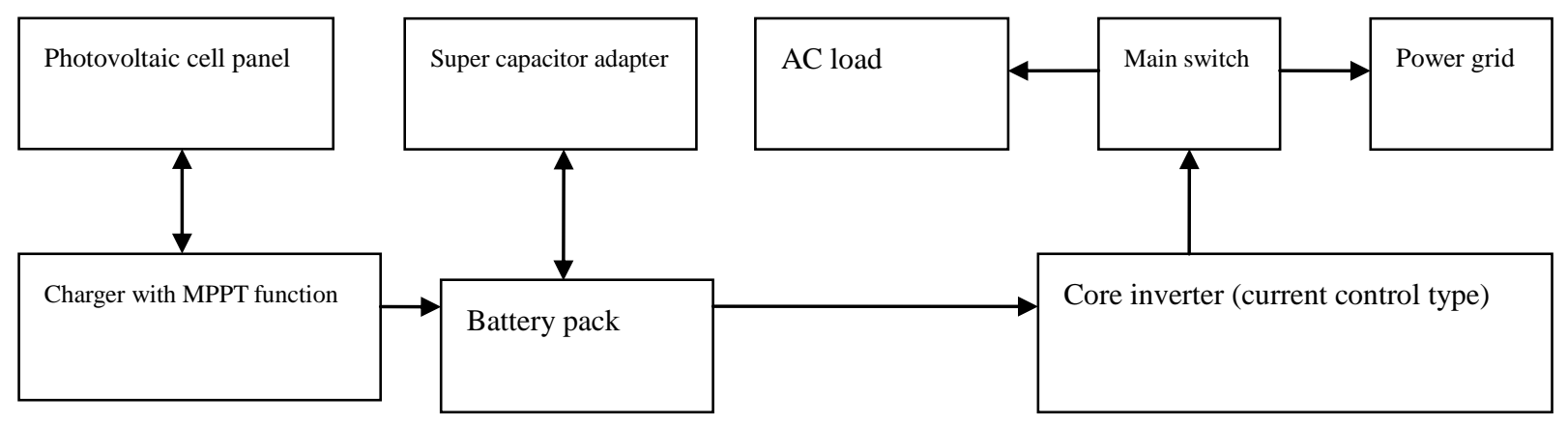

Figure 1. Schematic Diagram of Grid Connected Photovoltaic Power Generation System

\section{Conclusion}

The large-scale exploitation and utilization of fossil energy resources have resulted in the depletion of resources, climate change and serious environmental pollution problems, which have brought great challenges to the sustainable development of human society. Especially after entering the twenty-first century, the world's energy issues become more prominent, new energy and renewable energy sources become an effective way to solve the problem of energy. Therefore, new energy and renewable energy in the 21st century entered the period of a rapid development, has gradually become the strategic direction of the force of the global energy system and the development of energy in the future, human society is about to usher in the fourth energy revolution, the new energy revolution.

\section{References}

[1] Li Q Y, Han J P. The Risk Analysis of New Energy Power Generation [J]. Advanced Materials Research, 2014, 962-965:1787-1791.

[2] Araki I, Tatsunokuchi M, Nakahara H, et al. Bifacial PV system in Aichi Airport-site Demonstrative Research Plant for New Energy Power Generation[J]. Solar Energy Materials \& Solar Cells, 2009, 93(6):911-916.

[3] Fang B. The Fuzzy Mathematical Evaluation of New Energy Power Generation Performance [J]. Open Fuels \& Energy Science Journal, 2015, 8(1):238-243.

[4] Ya-Lou L I, Zhou X X, Lin J M, et al. A Review of New Energy Power Generation part in 2008 IEEE PES General Meeting[j]. Power System Technology, 2008, 32(20) 1-7.

[5] Gao M, Hou J, Zeng D L, et al. New Energy Power Generation Process Output Complementary and Coordinated Control [J]. Applied Mechanics \& Materials, 2012, 380-384:279-282.

[6] Yang Z H, Wang J, Chen L L. Application of Aid Design Program for Optical Fibre Cable line in Design of New Energy Power Generation [J]. Northwest Hydropower, 2014. 
[7] Yang W, Gao Y, Ning-Zhou X U, et al. Analysis of the New Energy Power Generation Technology [J]. Electrotechnics Electric, 2009.

[8] Xiang Q, Jiang D H. Personnel Continuing Education Demand for New Energy Power Generation Industry[J]. East China Electric Power, 2013.

[9] Feng L. The control strategy of the new energy power generation system [J]. Electronic Test, 2014.

[10] Shen Z. Index system for environmental impact assessment of new energy power generation project plans [J]. Huadian Technology, 2012, 64(10):367-399.

[11] Yang Z, Shao Z Z. Design and Realization of New Energy Power Generation Information Intelligent Management and Control System [J]. Computer \& Modernization, 2012, 1(11) 103-107.

[12]Zhang W B, Pan Y C, ZHANGWei-dong, et al. Analysis on Problems and Countermeasures of New Energy Power Generation in China [J]. Electric Power, 2012, 45(9) :48-51. 